\title{
Promoting ethical response-ability in the classroom through Science Fiction Literature: A feminist close reading of Joanna Russ's The Female Man
}

Florencia Gutiérrez Repetto. Universidad de Granada

Adelina Sánchez Espinosa. Universidad de Granada

Recepción: 08.05.2019 | Aceptado: 30.10.2019

Correspondencia a través de ORCID: Florencia Gutierrez Repetto

iD $0000-0002-2972-6759$

Citar: Gutierrez Repetto, F. y Sanchez Espinosa, A. (2019). Promoting ethical response-ability in the classroom through Science Fiction Literature: A feminist close reading of Joanna Russ's The Female Man. ReiDoCrea, 8, 282-291.

Financiación: Plan Propio de Investigación y Transferencia de la Universidad de Granada (2017): "Beca de Iniciación a la Investigación para estudiantes de Grado"

\begin{abstract}
Literature can be a powerful tool in promoting ethical response-ability within the classroom if analysed from feminist perspectives. Besides, when certain literary subgenres, such as Science Fiction, are approached from feminist methodologies the potentialities are multiplied. Feminist close reading, which foregrounds gender as critical concept and considers a number of external factors to the production and reception of a text, may be a way of helping students to develop their critical abilities when they are faced with any kind of text. In this paper, we take Joanna Russ's The Female Man (1975) as a case study in order to show how feminist close reading may widen the range of interpretations of a text, mainly by considering, on the one hand, the context of production of that text - written at the peak of the so-called second wave feminism - and, on the other, the location from which it is analysed. The result is an alternative, "oppositional" reading of the novel which attempts to overcome the shortcomings of the ideological stances that gave shape to it and restore its potential for a $21^{\text {st }}$-century context. To that end, a literary critic needs to display the pressures at work in the crafting and understanding of a text, which seems essential in the process of resisting the dominant meanings foisted on the reader. As a result, the critic is able to question a text and the alleged authority of its author. We aim at illustrating that, in the context of the classroom, this process may be of use in the upbringing of ethically responsible/response-able adults, which is, indeed, an essential task given current neoliberal individualism.
\end{abstract}

Keywords: Literature | Feminist Close Reading

Título en español: Generando responsabilidad en el aula a través de la Ciencia Ficción: Una lectura crítica feminista de The Female Man de Joanna Russ

Resumen: La literatura puede resultar una poderosa herramienta en la promoción de una responsabilidad ética dentro del aula, especialmente si se analiza desde perspectivas feministas. Asimismo, cuando se examinan determinados subgéneros literarios, como la ciencia ficción, utilizando metodologías feministas, sus potencialidades se multiplican. Una lectura crítica feminista, que prioriza el género como concepto crítico y tiene en cuenta factores externos a la producción y recepción del texto, puede ser una manera de ayudar a los estudiantes a desarrollar sus habilidades críticas a la hora de enfrentarse a cualquier tipo de texto. En este artículo, tomamos la novela de Joanna Russ The Female Man (1975) como caso de estudio para mostrar cómo una lectura crítica feminista puede ampliar el abanico de interpretaciones de un texto, al considerar, por un lado, el contexto de producción de un texto (en este caso, escrito en pleno auge de la llamada segunda ola feminista) y, por otro, la ubicación desde la que se analiza. El resultado de este proceso es una lectura alternativa y "oposicional" de la novela, que pretende superar las limitaciones propias de las posiciones ideológicas que dieron forma al texto y, a su vez, restaurar el potencial de éste para hacerlo válido en el siglo XXI. Con este fin, el crítico ha de exponer las presiones que se ejercen en la creación y en la comprensión de un texto, esenciales a la hora de resistir los significados dominantes que se intentan imponer al lector. Como consecuencia de esto, se hace posible el cuestionamiento del texto y de la supuesta autoridad de su autor. Nuestro objetivo es ilustrar cómo, en el contexto del aula, este proceso puede ser útil en la formación de adultos responsables, algo que es, sin duda, una tarea fundamental dado el individualismo neoliberal que se impone en nuestros días.

Palabras clave: Literatura | Lectura crítica feminista 


\section{Introduction}

The current decade has witnessed the emergence of conservative forces in Europe, the United States and other parts of the world, which has brought into light a crisis of values in Western societies. Racism, sexism and all types of phobias against otherness and difference, xenophobia or homophobia, among others, are growing all over, a repercussion of the economic crisis of the end of the preceding decade and the subsequent neoliberal austerity policies implemented by European governments. Consequently, many of the human rights achievements reached throughout the second half of the 20th century in pursuit of a more equal and just society, seem to be at stake right now.

The connections between the present crisis of values and the need for collective action is an issue that occupies current critical approaches in gender scholarship. Using artherapy as methodology, Ángela Harris and Adelina Sánchez (2017), for instance, highlight the urgency of acting on educational policies in order to make social commitment and responsibility a global issue (p. 131). Indeed, a reform of our educational systems and teaching dynamics may be the one and only way to confront this conservative backlash. From a feminist perspective, this change would have to focus on a re-building of bridges and a forging of unity based on differences and diversities. In this article we want to contribute yet another tool to this educational action: that of science fiction literature. We contend that, by making use of the space opened by science-fiction literature, students may be encouraged to challenge others' and their own "fixed" positions and identities, so that we would help to foster a type of education that would cherish differences and override the individualism promoted by neoliberalism. Furthermore, by training students in techniques of feminist close reading, their critical skills will be enhanced so as to read between the lines and oppose the most obvious dominant contents of the texts they encounter, hence helping generate more conscious and response-able people capable of engaging in a difficult world in need of solidary citizenship.

The case study proposed in this article is Joanna Russ's The Female Man (1975), a novel traditionally classified as belonging to the so-called second wave feminism. Following a feminist close reading (Lukić and Sánchez 2011) as our methodology, we intend to illustrate how a text shaped in the context of fervent identity politics may generate spaces for reflection, debate and reinterpretation of some of the concepts and ideas characteristic of those years. Its ethnocentrism and short-sightedness regarding intersectionalities may well come to the surface when we bring these tenets to the 21st century context and we close-read the text from a feminist perspective. The restoration of the subversive potential of the novel will then prove the potential of literary texts to dismantle fixed positions and ideologies, given the multiple possibilities they provide in the analysis of political and social realities. This, in turn, will show that within the classroom the students' critical abilities may be strengthened by encouraging them to approach texts from their own situated perspective, challenging certain meanings but also recognising the different pressures at work both in the production and interpretation of texts.

\section{Methodology: Feminist close reading}

In their review of approaches to close reading techniques by feminist scholars, Jasmina Lukić and Adelina Sánchez pay special attention to Sarah Mills' observation that within the field of literary criticism, close reading has long been considered a formalist approach to texts whereby the analysis of textual evidence should contain the ideas or intentions of its author (Mills 1995, p. 21). Since this text itself was seen as "a transparent medium 
which carries the ideas of the author" (p. 20), little attention was paid to questions such as gender, race or class, since they were said to bias the analysis and would, thus, affect the neutrality or objectivity of reading (p. 18). Given the stability of the text, which is supposed to remain the same over time, the conventional technique of close reading, which performs the analysis focusing only on textual evidence, may give the impression of producing an ahistorical, neutral analysis, valid from any point of view and, consequently, incontestable. Nonetheless, the social nature of language and the wide range of pressures at work, not only in the production of a text, but also in its interpretation directly challenge the neutrality of such analysis. Analysing a text by considering only the elements explicitly stated in it would mean that the critic is ignoring, for instance, what ideology may have shaped the production of that text or the mindset and location from which the critic analyses it.

With the purpose of overcoming the shortcomings of the conventional approach, Lukic and Sánchez (2011) propose a revamping of close reading as feminist close reading, which would entail, on the one hand, the consideration of extra-textual factors in the analysis; and, on the other, the "foregrounding of gender as a critical concept" (p.105). Taking it from here, we aim at crafting what Sara Mills's (1995) refers to as oppositional reading, which would be the result of a process of negotiation of meanings with the text, taking into consideration its context of production and reception, i.e., the location from which an interpretation or a reading is being made.

Out of the many factors that go into the production of a text, the author's affiliations and sociohistorical factors should be the focus of analysis. Sara Mills (1995) defines author's affiliations as "the conscious links individuals make to situate themselves as individuals" (p. 23), such as those to their gender, race, class, political stance, etc. These choices are limited by a "range of affiliative possibilities which are signalled within each society at the local or the national level" (p. 23), and where the sociohistorical factors corresponding to certain time or place have an essential role. However, the sociohistorical factors are not only relevant when it comes to look into the context of production of a text, but also in the circumstances surrounding the reception and subsequent interpretation of it. Hence, it is possible to assert that both the author and the reader are not isolated when writing and interpreting a text, but partially "formed by the extent to which [they] identify with a variety of possible social categories" (p. 25).

Bearing all these elements in mind, the critic of a text may proceed with a more solid support for a contextualised, feminist analysis if compared to the conventional, ahistorical approach. Once the lack of fixity of language is taken into consideration, a close textual analysis may be carried out by looking for the cues of interpretation that link the formal textual aspects with the extra-textual factors already mentioned. The spotting of these cues allows the critic to recognise how this influence is occurring and, consequently, the dominant reading of the text.

The dominant reading of a text can be defined as "a position (or positions) which the text offers or proffers to the readers within a particular historical moment, because of the range of ideological positions available which make the text understandable" (Mills 1995, p. 56). In other words, this reading is the one reinforced within the culture of the time when the text is produced. In order to lead the reader into this particular reading, the text addresses her or him either directly (e.g. through the use of vocatives such as you) or indirectly. The latter way of addressing is carried out mainly by making use of the notion of obviousness, i.e., certain information is presented to the reader as obvious and it is understood by her or him as being so. Such reader becomes "the type of people to whom this information would appear to be self-evident" (p. 53). She or he is interpellated by 
the text into a position that has been accepted by understanding that information as obvious, thus becoming what the text implies her or him to be.

Confronted with such "dominant reading", the critic can resist certain meanings and arrive at an "oppositional reading". Crafting the latter does not entail the total dismissal of all the meanings but merely the resistance towards some of them while still recognising the validity of others. And always taking into consideration that our readings as critics are not fixed but rather deeply influenced by our locations and backgrounds.

\section{The crisis of identity politics and the role of solidarity}

With the purpose of performing a thorough analysis of Joanna Russ's The Female Man (1975), dealing with the context of production of the novel is needed. Additionally, and overview of the changes undergone through the following decades up until our days is essential to the aim of locating the context from where the text is being interpreted.

\section{A case study: Joanna Russ's The Female Man (1975}

Probably the clearest of Joanna Russ's affiliations and the most outstanding sociohistorical factor which delimited the production of the novel was the outburst of the second feminist wave. Issues raised by theorists such as Kate Millet or Shulamith Firestone in the 1960s and 1970s are present in the novel. The most important postulate made during these years had to do with the fact that the oppression exerted against women was the result of a system of power relations that were realised in the public spheres - that is, public and cultural representation, economic independence, etc.-and in what was thereto considered as personal or private spaces-motherhood, marriage, sexual relationships (Gamble 2000) which were now being vindicated as just as public. Behind this all-pervading oppression there was a political institution referred to as patriarchy.

In order to fight that oppression, feminists at the time attempted to raise consciousness among women about the internalisation of patriarchal ideology with the purpose of appealing for unity, for what they named sisterhood. Sisterhood was based on female solidarity and cooperation, and on the assumption that, since all women shared certain experiences and underwent, consequently, the same oppression under patriarchy, they had to come together against androcentric power structures (Gamble 2000, p. 136). A common identity, women, was assumed based on a common experience which, no matter what other conditions surrounded them, was shared by all women.

The latter definition of sisterhood and other issues raised during the second feminist wave came in for fierce criticism in the following decades. The assumption of a common female experience as the basis for feminist sisterhood was directly related to the fact that 1970s, mainstream feminism was in fact a product of white, Euro-American ethnocentrism. In this appeal to a common oppression, other axes of oppression such as race, class or ethnicity were either overlooked or considered secondary to the feminist cause. As Chandra Mohanty asserts: in the fight against a 'universal' gendered oppression, "other categories of race and class ha[d] to be invisible for gender to be visible" (2003, p. 107). The main problem lay in the way the collective identity-i.e. the homogeneous group called women-was being articulated. The position from which this identity was being forged, namely, the view of the white, college-educated, EuroAmerican women, saw their location as a neutral, unmarked one, something that led to the invisibilisation of differences within the very group of people who formed the collective identity of women. 
In spite of all the criticism, the notion of sisterhood was not rejected altogether: either in the form of coalitions or from the perspective of solidarity, unity remained a crucial issue throughout the upcoming development of feminisms. In coalitions, difference came to play a crucial role, downplaying the once all-powerful commonality. By acknowledging "the meanings attached to gender, race, class, and age at various historical moments" (Mohanty 2003, p. 118), the members of coalitions could go beyond themselves and understand intersecting struggles, such as antiracist, anti-imperialist or gay and lesbian, which are, from this perspective, fundamental for feminist political strategy. This plurality of differences needed to be examined within collectives and political subjects, providing thus a safe ground for the temporary pursuit of specific shared goals.

Since the engagement with others' struggles may end up in the elimination of one's own privileges -if, from that location, the individual is, consciously or not, participating in or contributing to other women's oppressions (hooks 1984)-a further element is fundamental for the coalition to work: solidarity. Particularly compelling in this respect is Jodi Dean's notion of reflective solidarity, where she proposes the construction of a "communicative we", that is, the creation of bonds through a dialogic practice which involves dissent and critique (Dean 1996). This communicative model of solidarity entails that the shared goals of a coalition would be always open to debate, which would endow the collective with a dynamism that opposes the fixity of a collective identity based on being a woman.

The implications of this solidarity may be illustrated by María Lugones' (2003) metaphorical concept of identification through 'world-travelling', which requires "seeing what it is to be them and what it is to be ourselves in their eyes" (pp. 83-84). By doing this, we may discover that those that are constituted as objects of oppression in the mainstream view "are really subjects, lively beings, resisters, constructors of vision" ( $p$. 84). This process also requires what Lugones calls a "playful attitude" which, contrasting with identification as appropriation-i.e. imposing one's own sense of order and erasure of the other's world-, involves an "openness to surprise, to self-construction and reconstruction" (p. 33). A "playful attitude", therefore, may trigger a change in our own identity, facing thus the risking of "the ground that constructs us as oppressors and oppressed or as collaborating or colluding with oppression" (p. 33).

Bearing all these elements in mind, we carried out an analysis of Joanna Russ's The Female Man (1975) attempting, first, to spot the cues of interpretation that would lead the dominant reading of the novel. Secondly, we aimed at crafting an oppositional reading based on the background provided by the development undergone by the feminist movements during the decades following the production of the text, a background that gave shape to our current interpretation of the text and is, therefore, part of the context of reception.

\section{The Female Man (1975): A Feminist Close Reading}

The Female Man (1975) begins with a brief introduction of Janet Evason, a woman from a utopian, futuristic world, called Whileaway where, almost one thousand years before her time, a plague killed all the men. Thanks to a technology developed in Whileaway that allows her to travel along different universes, Janet appears suddenly in Jeannine Dadier's world, a 1960s United States where Great Depression never ended. Once there, she takes Jeannine into Joanna's world, the United States in the 1969 of our timeline. Joanna is presented as a character who is continually struggling against the gender differences and sexism of her world. In order to have a life different from those women whose only purpose is to fulfil men's needs, she decides to adopt the ways and attitudes traditionally linked to men: she calls herself "the female man". In Joanna's world, Janet 
strives to understand a culture where women are widely believed to be inferior to men, where sexual harassment is commonplace. This seems unconceivable to her, not only because of the lack of men, but most importantly because of the Whileawayan worldwide, kinship-based web. which shows the importance of communitarian values within this portrayal of utopia.

At one point, Joanna, Jeannine and Janet get to Jael's world, where a war between women's and men's societies has been waged for forty-years. Jael reveals that it was her who brought all of them together and that they are four versions of the same woman (the four J's). After showing the reality of "Manland" and "manlanders", who believe in the utter inferiority of women and mutilate those children who do not show signs of being 'real men' to use them as "women" (i.e., as sexual subordinates), Jael confesses the reason why she gathered them all together: She wants to create bases in the other women's worlds, so that, with their help, men's rule could be overthrown. Whereas Jeannine and Joanna agree to join Jael, Janet refuses arguing the pacifism of her people. At that moment Jael reveals that it was not a plague what made men disappear from Whileaway, but a war of sexes which was fought a thousand years before in Janet's timeline, where women killed all the men. Janet refuses to believe it, while the others rejoice at her incredulity. However, Jael, Joanna and Jeannine knew that the utopian, pacifist Whileaway was their only hope to keep fighting. The novel is left open-ended, with the four women returning to her own world and having experienced a change that affected their lives forever.

\section{Calling for sisterhood}

Even though there are several elements within Russ's novel that would allow a thorough analysis of its context of production, for this article we focus on the depiction of the utopian setting, Janet's Whileaway, which can be seen as the literalisation of many of the propositions put forward by feminists of the second wave. As way of example, Whileaway is described in the novel as a highly technologically advanced world, where several scientific breakthroughs have been made, such as hovercrafts, the "re-invention" of extinct animal species, the control of intelligence as an inheritable factor, a type of "genetic surgery" through the "merging of ova" (which allowed women to procreate without men), or "probability mechanics"-which allowed "teleportation" to other worlds or "probabilities" (Russ 1975, pp. 12-13). This technological control contrasts with the reality of the time and the status of female factory workers, whose precarious situation and lack of access to knowledge related with technology kept them as a dependency class (Millet 1969). This analogy between the novel and second-wave-feminism proposals supports the idea that sociohistorical factors and authors affiliations shaped the production of the text.

Although many other instances of the influence of extra-textual factors can be spotted in the text, my analysis will deal mainly with the relationship between this utopian setting and the calling for sisterhood characteristic of the second feminist wave. Of particular interest in relation with this topic was the worldwide, communal web of Whileaway, which, as mentioned above, highlights the importance of community and sisterhood in this world. It is depicted as follows:

There's no being out too late in Whileaway, or up too early, or in the wrong part of town, or unescorted. You cannot fall out of the kinship web and become sexual prey for strangers, for there is no prey and there are no strangers-the web is world-wide. In all of Whileaway there is no one who can keep you from going where you please (though you may risk your life, if that sort of thing appeals to you), no one who will follow you and try to embarrass you by whispering obscenities in your ear, no one who will attempt to rape 
you, no one who will warn you of the dangers of die street ... While here, where we live! (Russ 1975, p. 81; italics in original)

This extract is relevant since it does not only exemplify the freedom and independence women enjoyed in this world, but also because it contains several textual cues that point at the way in which the narrator is addressing the reader, a crucial point in the identification of the dominant reading of this novel.

Deixis in the use of vocative you ("no one who can keep you from", "no one will follow you", "try to embarrass you", etc.) and we ("While here, where we live-!") is how the text of this extract addresses the reader directly. On the other hand, the reader is also addressed indirectly through the inclusion of certain assumptions that are expected to be known and understood by her. Statements, such as "no one will follow you and try to embarrass you" or "no one who will attempt to rape you, no one who will warn you of the dangers of die street", when juxtaposed to "While here, where we live-—!", carry certain implications: First, that the reader and the narrator share the same location (in this case, "here", this world as opposed to Whileaway); and, second, that the reader knows that the circumstances depicted as unimaginable in Whileaway are in fact not infrequent in her location. This assumed knowledge was articulated as obvious, so that its automatic understanding, coupled with the direct addressing through the use of vocatives, contributes to the interpellation of the reader as "a woman" in this particular location (namely, 1970s, United States). Thus, the implied reader was conceived as this woman, who knows that these circumstances of harassment and exposition to rape are very frequent in her location. Moreover, the use of we suggests that the narrator is calling for a connection to this reader, an appeal to unity and shared experience that is linked to the radical feminist call for sisterhood.

In other words, the address to the reader highlighted in this extract seems to aim at exhibiting to the implied audience of this novel-i.e. women-the possible utopia that could be achieved via sisterhood. The extract consequently aims at uniting them to end with the oppressive conditions they all share. This call for sisterhood, a crucial part of the second wave radical feminism of the time can be considered part of the dominant reading of this text.

Certain meanings within this dominant reading need to be resisted so that an oppositional reading may be crafted. Since the dominant ethnocentric assumption is that all women undergo the same types of oppression, based on the experience oft a (most probably) white, American or Western woman, other oppressions are ignored with the consequent dangers that women may face, such as racism, heterosexism or those based on class, to name only a few. It may be said, then, that these oppressions are simply obliterated.

Accordingly, the kind of utopia appealed to as a goal in the text is to be reached through a sisterhood based exclusively on the category of women, not paying attention to the power relations within this group, nor to the various kinds of oppression that women from different ethnic or class groups may face. It is understood that, once this unity is achieved, all other oppressions will just vanish, discarding thus completely the possibility that uneven power relations may also appear in an all-female society too and the utopia will result in a reproduction of the contemporary power dynamics that they meant to struggle against.

\section{World-travelling in the forging of a new identity}

From our current cultural stance, the depiction of the utopian world, as such, has many fault lines that may allow the dismantling of the dominant reading, as the brief example 
shown above. Nonetheless, there are other meanings that may be acknowledged and recognised as valid from a $21^{\text {st }}$ century standpoint if we analyse them, for instance, from the perspectives of reflective solidarity and world-travelling.

Even though the four J's are united because they possess a common biological, genetic pattern, their coming together and travelling to each other's worlds may also be construed metaphorically, as a way of identification with one another. Their experiences in each other's dimensions are useful to illustrate the different attitudes adopted in worldtravelling as depicted by Lugones (2003). For instance, Jael's imperialistic attitude makes her attempt to impose her own sense of order (based on war), which may, in fact, lead to the erasure of the others' worlds. Thus, whereas the one rejected at the end by the other three J's is Janet -"Janet, whom we don't believe in and whom we deride" (Russ 1975, p. 206)- and this is so because of her refusal to participate on Jael's war, it is the latter's disregard for Janet's pacifist world and all its people which seems inadequate because of its imperialistic aim.

Nonetheless, Janet's attitude, which makes her flee after her disagreement with Jael, is not effective in the creation of a coalitional collective identity either. She sticks to her (resistant) community, rejecting altogether the possibility of providing any help to the other J's (even in terms different to those proposed by Jael) and ignoring what she witnessed when she travelled into their world and saw the oppressions they suffered. This reveals that outside the frame of a type of solidarity that accepts uncertainty, questioning and disagreement, identification fails, and so the forging of unity.

Conversely, Joanna's encounter with Janet and the travelling to her world changes her perspective completely. Janet and the Whileawayan society, based on communitarian values and where women are finally seen as complete, self-confident subjects, become Joanna's new interest and instil a "renewed zest of life" in her (Russ 1975, p. 29). Furthermore, even though she despises Jeannine throughout the novel- "Stupid and inactive. Pathetic. Cognitive starvation" (Russ 1975, p. 92)—Joanna commits herself to engage in a struggle alongside her. The conception she has of herself is affected by the travelling to the others' worlds, which can be seen as a metaphor of how the dialectic practice that entailed a transformation in her identity. Her attitude, open to surprise and self-reconstruction, allows the building of a coalition and challenges the static, singular notion of identity.

On the whole, an alternative "oppositional" reading of Russ's The Female Man (1975) allows an interpretation of the novel that eludes the essentialising of women's experiences and contributes to the understanding of identity (either collective or individual) not as a 'barred room', but as a fluid construct that may allow the forging of coalitions, which encompassing the differences of women's experiences. Thus, a new identity of women may be forged, a fluid, complex and ever-changing one which may be a more solid and resistant foundation for a mass-based feminist movement.

\section{Conclusions: the educational implications of feminist close reading}

The analysis of the case study chosen, Joanna Russ's novel, has served to illustrate that the dominant reading of a text could and should be resisted and an that an oppositional, contextualised reading can and must be fashioned as a way to make ourselves accountable as critical response-able readers. Indeed, feminist close reading fosters critical thought and encourages readers not only to be aware of the concealed meanings which lead to a dominant reading, but also to go beyond and perform an analysis which, far from being ahistorical or neutral, is actually situated. 
At this point, let us bring here Donna Haraway's (1988) perspectives on the objectivity of situated knowledges. She states that objectivity is "not about the false vision promising transcendence of all limits and responsibility", but that "only partial perspective promises objective vision" (p. 583), the result from which she refers to as situated knowledges. This concept seems crucial in the analysis of a text through the method of feminist close reading: Understanding and acknowledging one's own location (including privileges) is essential for a contextualised, solid analysis.

In the context of the classroom, encouraging students to approach texts through the method of feminist close reading may be an efficient way of showing them how to be critical with the meanings that are foisted on them by texts themselves, to acknowledge the location from where they are performing the analysis and to vindicate its validity as a critical stance. As a result, they would see that authors are not incontestable authorities regarding their texts, but that the latter are a result of the combination of several pressures at work in the contexts of situated production and situated reception of the text. This perspective will not only enrich the debate when analysing literary texts, but it will also give students tools to challenge other meanings outside texts, which can also be contested, so that their perception of the social and political reality would be more critical, hence helping the generation of a more response-able reading not only of the text but also of their own social and political milieux.

Furthermore, the promotion of debate within the classroom from a situated perspective tallies up with other feminist concepts brought forth in this article: reflective solidarity and 'world'-travelling. Reflective solidarity may also come in handy within the classroom, where discussion and disagreement must be commonplace. By understanding disagreement as a way of building bridges, as a starting point for a communicative 'we' that must be worked out through dialogue and always in full awareness of their own location and relation to others. We will, indeed, be passing on to students our feminist best practices by teaching them how to travel to each other's 'worlds', making the process of learning from one another, not only a way of reaching a more just and comprehensive consensus, but a way of enriching a collective and even their own individual identities.

Since the ultimate aim of applying these ideas in the context of the classroom is to give young people the tools to critically comprehend and participate in social and political realities, a shift in the class dynamics towards one of a more dialectic and critical nature would contribute to a type of education that would allow students to challenge the homogeneous thought that has been imposed by neoliberalism, which fosters a rugged individualism and erases differences. By being critical towards alleged 'neutrality' and, at the same time, by cherishing diversity and opening themselves to embrace it, a more open, just society may be achieved.

\section{References}

Dean, Jodi (1996). Solidarity of Strangers: Feminism after Identity Politics. University of California Press.

Gamble, Sarah (2000). The Routledge Critical Dictionary of Feminism and Postfeminism. London, UK \& New York, NY: Routledge.

Harris, Angela and Sánchez Espinosa, M. Adelina (2017) Feminist Ethics of Responsibility and Art therapy: Spanish Art Therapy as a case in point. In Teaching Gender: Feminist Pedagogy and Responsibility in Times of Political Crisis (pp. 131-145). London and New York, NY: Routledge.
Haraway, Donna (1988). Situated Knowledges: The Science Question in Feminism and the Privilege of Partial Perspective. Feminist Studies, 14(3), 575-599.

hooks, bell (1984). Feminist Theory: From Margin to Center. New York, NY: Routledge.

Lugones, María (2003). Pilgrimages/Peregrinajes: Theorizing Coalition against Multiple Oppressions. Lanham, MD: Rowman \& Littlefield Publishers. 
Lukić, Jasmina and Sánchez Espinosa, Adelina (2011). Feminist Perspectives on Close Reading. In R. Buikema, G. Griffin, N. Lykke (Eds.), Theories and Methodologies in Postgraduate Feminist Research (pp. 105-118). London, UK and New York, NY: Routledge.

Millet, Kate (1965). Sexual Politics. Chicago, IL: University of Illinois Press.
Mills, Sara (1995). Feminist Stylistics. London, UK: Routledge.

Mohanty, Chandra T. (2003). Feminism without Borders: Decolonizing Theory, Practicing Solidarity. Durham and London, UK: Duke University Press.

Russ, Joanna (1975). The Female Man. London, UK: Orion Publishing Group. 